\title{
G.J. Steyn
}

\section{TORAH QUOTATIONS COMMON TO PHILO OF ALEXANDRIA AND THE ACTS OF THE APOSTLES}

In honour of Hermie C. van Zyl

\begin{abstract}
It is the intention of this contribution to investigate the text form of the LXX Torah quotations that overlap between the works of Philo of Alexandria and the Acts of the Apostles. It forms part of a larger project which investigates the common use of a possible Old Greek Version by both Philo and the New Testament. Six cases are investigated of which five are present in Stephen's Speech in Acts 7. There were no clear traces found of another Textvorlage of the Torah that was used by Luke and/or Philo in these cases. Luke's quotations here resemble adaptations and interpretations already made in the Christian tradition by his time. Several cases show evidence of conflations and paraphrases of the quoted passages. Noteworthy, however, is that Philo's text form and that of the reconstructed LXX text are very close in the cases investigated here. Where Philo notably differs from the reconstructed LXX text, Luke tends to represent a text form that is in closer alignment to that of the LXX than to that of Philo.
\end{abstract}

\section{INTRODUCTION}

In a recent study of the Septuagint $(L X X) \operatorname{Vorlage}(n)$ underlying the explicit quotations in the anonymous book "To the Hebrews", it became clear that nearly all Hebrews' quotations from the Torah (as well as the longer quotation from Prov 3:11-12 in Heb 12:5-6) were also to be found in the Corpus Philonicum - especially in Legum allegoriae III. Furthermore, apart from the overlap in occurrence, also the text form of all those explicit Torah quotations (allusions and references excluded), is in agreement with the form of the quotations as found in Philo - against those text forms of the

Prof. Gert J. Steyn, University of Pretoria. E-mail address: Gert.Steyn@up.ac.za 
Masoretic Text (MT) and the LXX (Steyn 2006:135-151). Both Hebrews and Philo together deviate from the readings of the MT as well as from the LXX witnesses. ${ }^{1}$ This leads to some obvious questions: Did both Hebrews and Philo (independently?) know and use the same version of the Scriptures, i.e. a common earlier LXX version than that known to us today in its reconstructed editions? (Such a theory might actually even strengthen possible Alexandrian commonalities between the two). Furthermore, do we have here evidence of an earlier LXX text form? No wonder that the relation between the quotations in Philo's works and the text form of the LXX had been a topic of interest in the past. ${ }^{2}$

Drawing on the conclusions of the study on Hebrews, it became obvious that the phenomenon ought to be investigated in the rest of the New Testament as well. It is the intention of this contribution to investigate those Torah quotations that overlap particularly between the Lukan literature and the works of Philo of Alexandria. ${ }^{3}$ This forms part of a more extensive project. Previous studies were already conducted regarding the overlaps between Paul's letters to the Galatians (Steyn 2012:444464), Corinthians (Steyn 2013a) and Romans (Steyn 2013b), as well as the gospels according to Mark and Matthew (Steyn 2013c).

The purpose of this investigation is merely to compare the text forms of the LXX Torah and its quotations in the Corpus Philonicum and the Lukan writings - here only Luke's second work, the Acts of the Apostles. It is thus not the intention of this study to investigate the hermeneutical aspects of these quotations within their new contexts, ${ }^{4}$ neither to elaborate on their function within the arguments of Philo and Luke. The focus of this study is exclusively synoptic in nature, i.e. it is aimed at determining the differences and similarities between the text forms in order to establish whether a

1 In the larger picture, D.T. Runia also pointed to the use of four texts in particular, namely Gen 2:2, Exod 25:40, Jos 1:5 and Prov 3:11-12, which are "so close to Philo that coincidence must be ruled out". Runia refers particularly to Heb 13:5b, "a composite text derived from Jos. 1:5, Deut. 31:8 and possibly Gen. 28:15, which is cited in exactly the same form by Philo in Conf. 166" (Runia 1993:76).

2 See, amongst others, the discussions in Runia (1993:24), Dell'Acqua (2003:2552) and Kraft (2005:237-54).

3 The manuscript tradition of Philo's works has been largely transmitted through the Christian tradition. This constantly poses the risk that Philo's text had been influenced by the Christian tradition. This, in turn, calls for extreme caution in comparative studies such as here. For this investigation the text edition of $P$. Borgen, K. Fuglseth and R. Skarsten (2005) will be used.

4 For an investigation of this nature, see Steyn (1995). 
common early LXX Textvorlage might be traced in Philo's writings and those of Acts.

\section{DISTRIBUTION OF THE TORAH QUOTATIONS}

Philo quotes the most from Genesis, then Exodus, then Deuteronomy, Numbers, and Leviticus. There are 11 explicit quotations from the Torah to be found in Luke's Gospel and 19 in the Acts of the Apostles, thus totaling 30 Torah quotations in the Lukan literature. Ten of these also occur in the writings of Philo of Alexandria. Three of these ten are to be found in Jesus logia in Luke's Gospel, ${ }^{5}$ whilst the remaining seven of the ten overlapping quotations occur in Acts - two of which are found in Peter's second speech (Acts 3) and five of them in Stephen's speech (Acts). ${ }^{6}$ One of these, the quotation from Exod 3:6/Exod 3:15, occurs in both Peter's speech and in Stephen's speech. This leaves us then with seven overlapping quotations, but only six cases to be investigated. It is striking that there are no Torah quotations that overlap between Philo and Paul's speeches in Acts. In fact, with the exception of a possible quotation from Exod 22:27 in Acts 23:5, ${ }^{7}$ situated in Paul's defense speech before the Sanhedrin, no quotations from the Torah are to be found in the Pauline speeches of Acts at all.

The fact that the overlapping quotations between Philo and Luke-Acts are situated in the speeches comes as no surprise, as it is long known that the explicit quotations are to be found almost exclusively in the speeches of Luke-Acts (Steyn 1995:24-30). Three of the ten cases overlap internally between Luke-Acts, as the quotation in Luke 20:37 (Jesus logion) occurs again in Acts 3:13 (Peter's speech) and Acts 7:32 (Stephen's speech). This leaves us ultimately with five cases to be investigated where there is an overlap between the Acts of the Apostles and the Corpus Philonicum - all of which appear in Stephen's speech in Acts 7. However, several of the remaining twenty explicit Torah quotations in Luke-Acts also overlap with allusions and references in Philo, whilst several explicit Torah quotations in Philo again overlap with allusions and references in Luke-Acts. These will, however, not be discussed within the limited space of this contribution.

$5 \quad$ Luke $4: 4 ; 18: 20 ; 20: 37$.

6 Acts $3: 13,25 ; 7: 3,6,7,18,32$.

7 Although Rese also considers this as an explicit quotation (1979:69), Swete, in turn, did not want to include it as a quotation (1900:388). 
Case 1: The quotation from Exod 3:6, 15 in Luke 20:37 (Jesus' Speech), Acts 3:13 (Peter's Speech) and Acts 7:32 (Stephen's Speech)

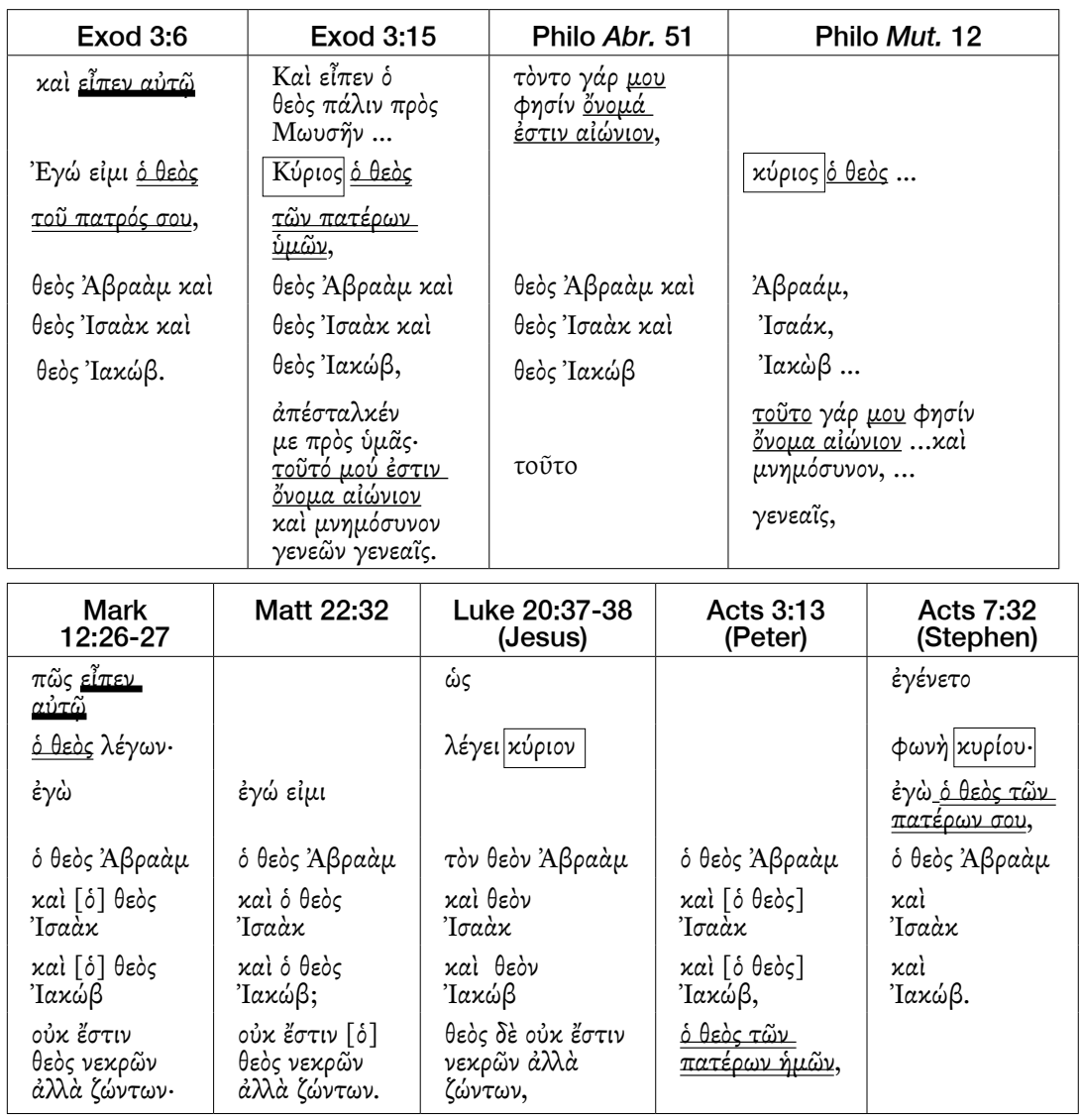

There are two possible sections in LXX Exodus from which Luke's quotations in Luke 20:37, Acts 3:13 and Acts 7:32 might have been taken from, namely LXX Exod 3:6 and/or Exod 3:15. ${ }^{8}$ The version of 3:6 has हĩ $\pi \varepsilon v$ a $\tau \tau \tilde{\omega}$ and uses $\dot{\varepsilon} \gamma \omega \dot{\omega} \varepsilon \dot{\varepsilon} \mu$ in reference to God introducing himself, as well

8 Cf., however, Barrett (2004:193): “...the words occur nowhere in the OT in precisely this form". He draws attention (p.194) to Wilcox (1965:29, 34) who sees a possible Samaritan connection here. 
as the genitive singular for $\delta \pi \alpha \tau \rho^{9}$ and for the second person personal

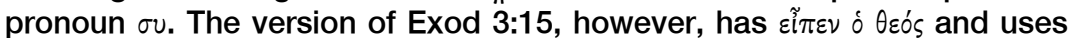
xúplos in reference to God referring to himself as well as the genitive plural for $\delta$ iatpós and for the second person personal pronoun. The Samaritan Pentateuch, as well as the Ethiopic and Boharic translations of Exod 3:6, also follow the genitive plural for $\delta$ iatpós and for the second person personal pronoun ${ }^{10}$ - similar to LXX Exod 3:15!

The two occurrences in Philo's works (Abr. 51; Mut. 12) where reference is made to this tradition are clearly closer to the version of LXX Exod 3:15 (than to the version of LXX Exod 3:6) as both of them contain the phrase

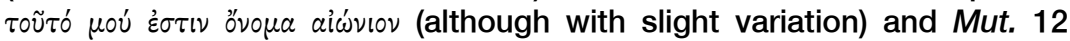
includes the reference to xúplos before $\delta \theta \varepsilon o ́ s .{ }^{11}$ None of the two reconstructed versions of LXX Exodus 3, or those of Philo, include the definite article $\delta$ before $\theta$ cós in reference to Abraham, Isaac and Jacob. ${ }^{12}$ However, codex Alexandrinus and a number of other manuscripts ${ }^{13}$ amongst the LXX witnesses do indeed include the definite article $\delta$ before $\theta$ sós in reference to Abraham! Their text-critical weight in relation to Vaticanus and Sinaiticus should, however, be considered as secondary. Some variants amongst

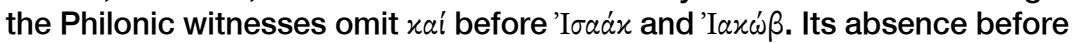
'I $\sigma \alpha \alpha^{\prime} x$ is closer to the MT, Complutensic Polyglot and the Targumim. ${ }^{14}$

9 The Samaritan Pentateuch, however, reads the plural here - against the Hebrew, LXX, Vulgate, and Peshitta (Barrett 2004:361).

10 G. Schneider (1980:449) quite rightly suggests: "Die von LXX abweichende Lesart beruht vielleicht auf lukanischer Redaktion. Abgesehen von dieser Erklärungsmöglichkeit kann auh hier ein textkritisches Urteil die auffallende Übereinstimmung zwischen Apg 7 und dem SP plausibel machen, ohne daß eine gegenseitige Abhängigkeit angenommen wird. Der pluralische Ausdruck begegnet nicht nur bei den genannten Zeugen für Ex 3,6, sondern auch im samaritanischen Targum, in den LXX-Handschriften $\mathrm{k}$ und $\mathrm{m}$, der bohairische Übersetzung und einem äthiopischen Kodex".

11 "According to Mut. 11f. the divine name given to men is xúplos $\delta$ erós. God also has a relative name by which men may call upon Him: 'I am the God of Abraham, Isaac, and Jacob, this is my name for ever,' Abr. 51, cf. Ex. 3:15" (Bietenhard 1967:264).

12 Caution is here in order as "the presence or absence of an article does not make a substantive definite or indefinite" in Greek (Porter 1999:103).

13 These are 15-64*-72-376 $C^{\prime-54} b 106 n \times 121-527$ z 1876130424509799 . They represent an extremely broad group of witnesses dating from the $10^{\text {th }}$ century onwards and mainly consisting of hexaplaric signs and catenae. Due to limited space, refer to J.W. Wevers (1974:55-59) for detailed information.

14 For a detailed account, see the critical apparatus of Exod 3:15 in the LXX edition of Wevers (1991). 
Mark's gospel, representing the earliest form of this reference in the gospel tradition, seems to be closer to the version of LXX Exod 3:6 as

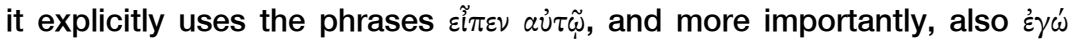
(omitted by codices $\mathrm{D}$ and $\mathrm{W}$ ) in reference to God's introduction of himself. Furthermore, the definite article $\delta$ appears now before $\theta$ cós in reference to Abraham and with disagreement amongst some textual witnesses, in reference to Isaac and Jacob. Matthew's version follows the Markan

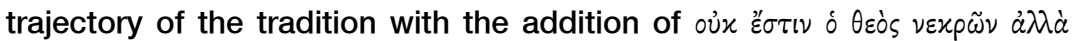
$\zeta \omega \nu \tau \tau \nu$ (cf. Mark 12:27; Luke 20:38), but expands on the quotation with the inclusion of $\varepsilon i \mu l$ after $\dot{\varepsilon} \gamma \omega \dot{\omega}$ as present in Exod 3:6 (LXX and MT).

Luke's version in Jesus' speech (Luke 20:37) shows closer similarities with the text form of LXX Exod 3:15 ${ }^{15}$ with its presence of xúplos (but in the accusative form $\left.{ }^{16}\right)$. Although there is disagreement in the manuscript tradition about the presence of the definite article, the preferred tradition excludes it with reference to Isaac and Jacob's God - similar to the LXX Exodus traditions and the two occurrences by Philo. There is agreement in the manuscript tradition, however, about its presence with reference to Abraham. The text form of the quotation from LXX Exod 3:15, as it appears in Luke 20:37, resembles that of Philo's Mut. 12.

Luke's other versions in the speeches of Peter (Acts 3:13) and Stephen (Acts 7:32) are also closer aligned with the textual tradition of LXX Exod $3: 15$ due to their inclusion of the phrase $\delta \theta \varepsilon \dot{s} \varsigma \tau \tilde{\omega} \nu \pi \alpha \tau \varepsilon \dot{\rho} \omega \nu$ in the plural ${ }^{17}$ and the absence of the definite article $\delta$ before Isaac and Jacob's God in Acts 7:32 (possibly also in Acts 3:13). The phrase $\delta \theta \varepsilon \dot{s} \tau \tilde{\omega} \nu \pi a \tau \varepsilon \dot{p} \omega \omega \nu$ is transposed to the end of the quotation and contextually applied to its audience in Peter's speech (Acts 3:13) with the $\dot{\eta} \mu \tilde{\omega} \nu$ at its end. It remains, however, in its original position in Stephen's speech (Acts 7:37) and is contextually applied with rov at its end. There is consensus in all the New Testament versions about the inclusion of the definite article $\delta$ before $\theta$ cós 'A $\beta$ paá $\mu$ against the LXX Exodus versions and those of Philo, but disagreement in the manuscript tradition regarding its inclusion also before $(\theta \varepsilon \dot{s} \varsigma)^{\prime} I \sigma \alpha \alpha \dot{x} x$ and

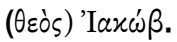

It can thus cautiously be concluded that the Markan trajectory (Mark 12:26) - followed by Matthew (Matt 22:32) - is closer to LXX Exod 3:6, whereas the Philo (Abr. 51; Mut. 12) and Lukan trajectories (Luke 20:37;

15 See also Kilgallen (1986:488), Nolland (1993:966) and Marshall (2007:545).

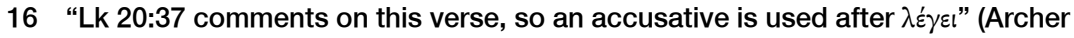
\& Chirichigno 1983:15).

17 According to Pesch (1986:253), the plural refers to the part of the speech that deals with the "fathers" and stresses the continuity of the deeds of God. 
Acts $3: 13 ; 7: 32$ ) are closer to LXX Exod 3:15. ${ }^{18}$ If this is the case, then Luke adjusted his quotation - originally taken from the Markan material used in Luke 20:37 - to be closer to the same trajectory used by Philo of Alexandria.

Case 2: The quotation from Gen 12:1-2 in Acts 7:3 (Stephen's Speech)

\begin{tabular}{|c|c|c|c|c|}
\hline Gen 12:1-2 & $\begin{array}{c}\text { Philo, Migr. } \\
1 \\
\end{array}$ & $\begin{array}{c}\text { Philo, Her. } \\
277 \\
\end{array}$ & $\begin{array}{c}\text { Philo, Leg. } \\
2,59 \\
\end{array}$ & Acts 7:3 \\
\hline 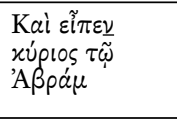 & 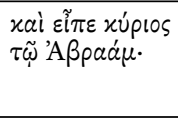 & 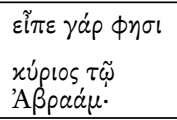 & 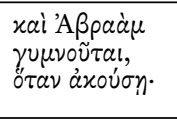 & 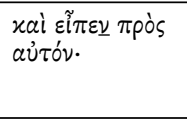 \\
\hline 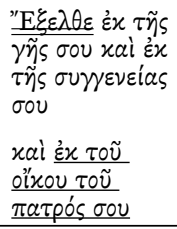 & 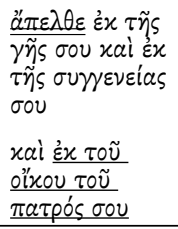 & 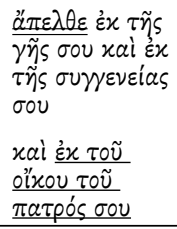 & 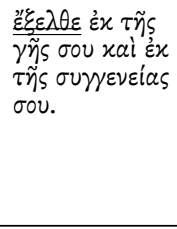 & 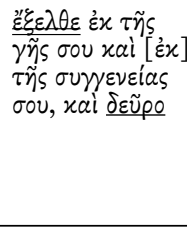 \\
\hline 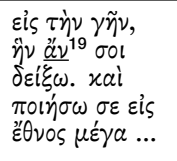 & 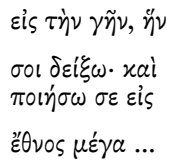 & 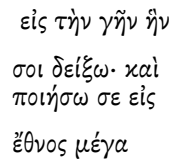 & & 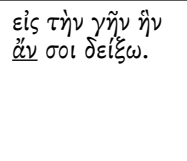 \\
\hline
\end{tabular}

Philo presents fairly extensive quotations of LXX Gen 12:1-2 in Migr. 1 and Her. 277, as well as a shorter quotation in Leg. 2,59. All three versions are in exact agreement with the LXX - apart from two differences:

a) The first is his use of $\alpha \dot{\alpha} \varepsilon \lambda \theta \varepsilon$ at the opening of his quotation in both Migr. 1 and Her. 277 instead of ${ }^{k} \xi \varepsilon \lambda \theta \varepsilon$ in LXX Gen 12:1. The latter occurs, however, in Leg. 2,59 and is also used by Luke in Stephen's speech in Acts 7:3.

b) The second difference between the Philonic versions and LXX Genesis 12 , is Philo's absence of the $\alpha v$ which appears in Gen 12:1 between $\eta^{\nu} v$ and $\sigma 0$.

18 G. Schneider (1980:462), however, considers Acts 7:30-34 as referring to LXX Exod 3:1-10a. He states: "V 32a gibt Ex 3,6a wieder, freilich ohne ei $\mu$ u und mit der pluralischen Formulierung vom 'Gott deiner Väter', V 32b entspricht Ex 3,6b".

19 Apart from Philo, is the particle $\alpha 2 \nu$ also omitted by 15-72' 319 and replaced by द́áv in 509. 
Luke's account of the quotation, in turn, presents an abbreviated version

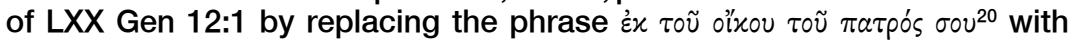
$\delta \varepsilon \tilde{\rho} \rho 0$ and hence emphasizing the aspects of movement and obedience. ${ }^{21}$ Targum Pseudo-Jonathan, however, also reads the equivalent of $\delta \varepsilon \tilde{p} \rho \circ$ in Gen 12:122 so that it "should perhaps be regarded as a variant reading" (Barrett 2004:342). ${ }^{23}$ Luke, furthermore, uses ${ }^{~}{ }^{\xi} \xi \varepsilon \lambda \theta \varepsilon$ at the opening of the quotation - as LXX Gen 12:1 does, followed by Philo Leg. 2,59, but contra Philo's ă $\pi \varepsilon \lambda \theta \varepsilon$ in Migr. 1 and Her. 277.

Case 3: The quotations from Gen 12:3; 22:18; $28: 14$ in Acts 3:25 (Peter's Speech)

\begin{tabular}{|c|c|c|c|c|}
\hline Gen $12: 3^{24}$ & Gen 28:14 & Philo, Migr. 1 & $\begin{array}{c}\text { Philo, Migr. } \\
118\end{array}$ & $\begin{array}{c}\text { Philo, Migr. } \\
122\end{array}$ \\
\hline $\begin{array}{l}\text { xal } \\
\dot{\varepsilon} \nu \varepsilon u \lambda \circ \gamma \eta \theta \dot{\eta} \sigma 0 \nu \tau \alpha l \\
\underline{\dot{\varepsilon} v \sigma o l}\end{array}$ & 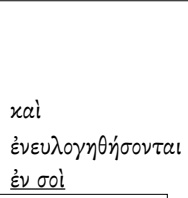 & 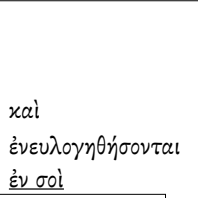 & 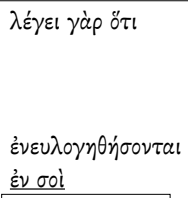 & 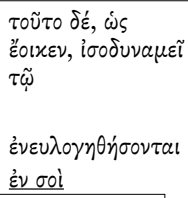 \\
\hline 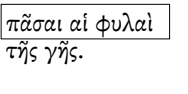 & 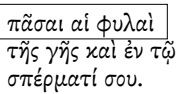 & 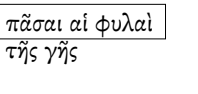 & $\begin{array}{l}\tilde{\alpha} \sigma \alpha \iota \text { ai } \phi u \lambda a i \\
\tilde{\eta} s \gamma \tilde{\eta} s\end{array}$ & $\begin{array}{l}\frac{\pi \tilde{\alpha} \sigma \alpha \iota \text { ai } \phi u \lambda a i}{\tau \tilde{\eta} \varsigma \gamma \tilde{\eta} s .} \\
\end{array}$ \\
\hline
\end{tabular}

20 R. Pesch (1986:248) is of the opinion that Luke omits the phrase because it does not fit to the departure from Mesopotamia and the death of Terah in Haran. This might be true - unless Luke's LXX Vorlage already omitted it. Furthermore, G. Schneider (1980:453) stated: "Ob der Verfasser der Rede Gen 12,1 'irrtümlich auf Abrahams ersten statt zweiten Auszug' bezieht, ist nicht sicher. Eher führt er die Wanderung Abrahams bewußt von Anfang an auf Gottes Initiative zurück. Selbst biblische Texte übergehen bei Angaben über den Weg Abrahams die Zwischenstation Haran (Gen 15,7; Neh 9,7)."

21 Cf. Barrett (2004:342): "In Acts the omission of from thy father's house was probably due simply to natural abbreviation; the thought was more or less

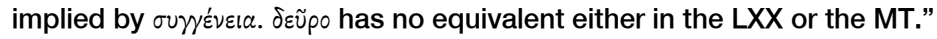

22 The same applies to several other LXX witnesses. These include M 17'-82135-426 C" b d 53-246 $n$ s 46-370 y z 5459509730 - as well as Basilius Seleuciensis 104; Chrysostom passim; Cyrillus Alexandrinus I,165; Eusebius 6,9; Theodoretus Cyrensis 3,760; Latin, Ethiopic, Arabic, Aramaic and Boharic translations (or $\delta \varepsilon \cup \rho \omega 52^{*} 53 n 343^{\prime} 121-318$ ).

23 Conzelmann (1987:52), however, pointed out that “...in Acts the departure, rather than from Haran, is from Ur, from which Abraham's father must also depart (cf. vs 4)." Referring to the thesis of Wilcox (1965:26-7), he correctly states that "It is not necessary to understand this as dependent upon the Palestinian Targum tradition". Emerton, too, argued that the similarity might be coincidental (1968:286).

24 Apart from the texts listed here in the synopsis, is Gen 12:3 also quoted in 1 Clem 10:3 and Jub. 12:23 (McLean 1992:21). 


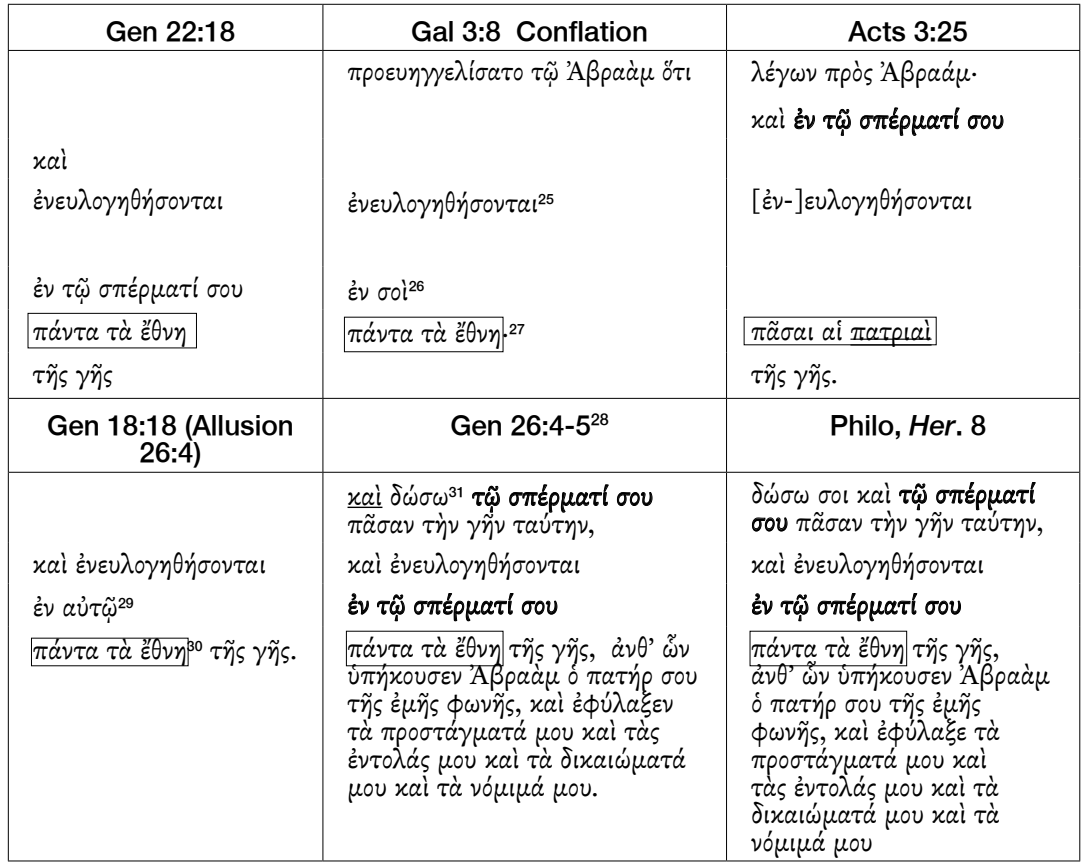

It is striking that there are two versions of the tradition here,$^{32}$ which confirm that the same tradition might have circulated in more than one

25 Koch pointed out that Paul agrees here with the oldest text form of the LXX by

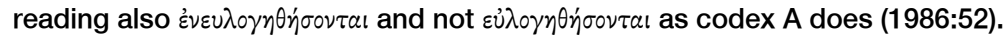

26 Wevers (1993:164) does not agree with Soisalon-Soininen (1987:126) that "an instrumental use of $\varepsilon \nu$ for persons is impossible in Greek" and he finds the statement to be "overly absolutistic". He interprets $\varepsilon \dot{\varepsilon}$ then here instrumentally and concludes "(T)hat 'all the tribes of the earth shall be blessed ' $\varepsilon \nu$ oo' then means that Abram through the " $\varepsilon^{\prime} \theta \nu \circ \varsigma \varepsilon^{\prime} \gamma \alpha$ which will become will be the source of blessing for all the tribes of the earth in the future".

27 The absence of $\tau \tilde{\eta} \varsigma \gamma \tilde{\eta} \varsigma$ here might either be the result of Paul's elective or conflated form of quoting the passage, or it might reflect its absence in codex Alexandrinus in Gen 22:18.

28 Gen 26:4 is also quoted in Acts 3:25; Jub. 24:10-11; Justin Dial. $120: 1$ (McLean 1992:26).

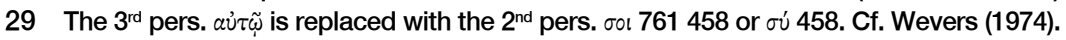

30 The phrase is replaced with $\pi \tilde{\alpha} \sigma \alpha l$ ai $\phi u \lambda$ ai by 25-646. Cf. Wevers (1974).

$\left.31 \delta \omega^{\prime} \sigma \omega\right]+\sigma o l$ ( $\sigma \nu$ 500) xaí 17-135-381' C"'-25 44'-370 t-799 42431 La (sed hab Aug C D XVI 36 Ps. Phil 29 Vulg) (Cf. Wevers 1974).

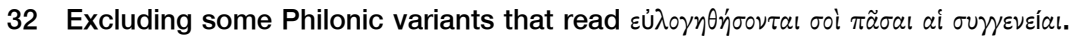
Cf. Wevers (1974). 
version from an early stage. The first version, or trajectory, of the tradition is found in LXX Gen 12:3 (with an allusion in 28:14), followed by Philo in Migr. 1, 118, and 122. The second version, or trajectory, of the tradition is found in LXX Gen 22:18 and 26:4-5 (with an allusion in Gen 18:18), followed by Philo in Her. 8 and by Gal 3:8. ${ }^{33}$ This latter version reads $\pi \dot{\alpha} \nu \tau \alpha \tau \dot{\alpha} \varepsilon^{\prime \prime} \theta \nu \eta{ }^{34}$ Also the quotation in Acts 3:25 is closer to the second version in its text

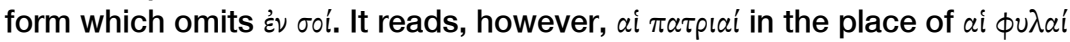

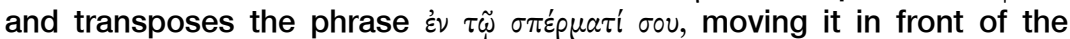

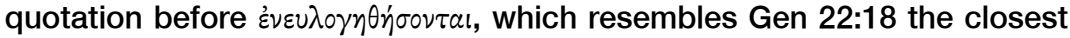
(Rese 1979:71-3). ${ }^{35}$

It is interesting that the NT authors preferred the second version of LXX Gen 22:18 and 26:4-5 with the more universal terms "nations"36 ( $\tau \dot{\alpha}$

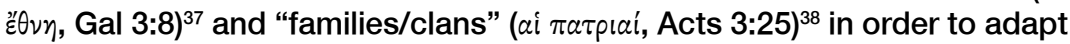
their quotation to the new contexts for which they are writing..$^{39}$ The object of the blessing moved here from the Jewish tribes to a broader audience.

Philo preserved thus both trajectories of the tradition: the LXX Gen 12:3 version in his Migr. 1,118, 122, and the LXX Gen 22:18; 26:4-5 version in

33 Ellis (1957:124) is of the opinion that this "reference is to Scripture as a whole" and points to the fact that "Repetitions of the promise are given twice in the hithpael (Gen. 22.18; 26.4), which has a reflexive connotation ('bless themselves'). But the Niphal וחברכו (Gen. 12.3; 18.18; 28.14) has only the passive signification 'to be blessed', and raul's rendering, as an interpretation, is proper even for the others". He thinks, furthermore, that "Gal. 3.8 (in) the NT and LXX 'be blessed' would, on the basis of statistical probability, better represent the Hebrew if it were reflexive rather than passive" (p. 140). He finally considers Gal $3: 8$ as belonging to those quotations that are "at variance with the LXX and the Hebrew where they agree" (pp. 150, 152).

34 See Soisalon-Soininen (1987:194-6) for a discussion of its concord with a plural verb.

35 It is unclear whether this is a free citation from memory or a conflation. For an extensive discussion of the quotation of Acts 3:25, see Steyn (1995:153-7).

36 So, similar, Koch (1986:163): "Erst durch die Abänderung mit Hilfe von Gen 18,18 enthält Gen 12,3 die für Paulus erforderliche Zuspitzung: die Geltung des Abrahamsegens nicht nur für die neutral als ai $\phi u \lambda \alpha i ́$ bezeichnete Menschheit allgemein, sondern ausdrücklich für die "

37 Cf. Gaston (1987:104): “'that God would justify the Gentiles from faithfulness' (3:8) is contained in Torah. This must be taken very seriously" (p. 81). Furthermore, "Paul is speaking explicitly about the situation of Gentiles in the enveloping verses 8 and 14" (My emphasis, GJS).

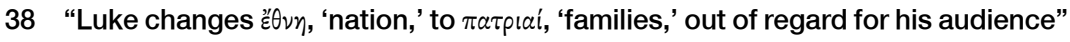
(Conzelmann 1987:30).

39 Similarly Marshall (2007:549). Against Wevers (1993:399): "The terms are intended as fully synonymous". 
Steyn Torah quotations common to Philo of Alexandria and the Acts his Her. 8. Paul, in turn, presents a conflated quotation by fusing together elements from the two versions of LXX Gen 12:3 and Gen 22:18; 26:4-5. Luke's version in Act s 3:25, however, is closest to LXX Gen 22:18; 26:4-5 as well as to Philo's Her. 8. Thus again, it is interesting to note that Luke clearly follows the second trajectory of the tradition, ${ }^{40}$ different to Paul who seems to merge the two. ${ }^{41}$

Case 4: The quotation from Gen 15:13 in Acts 7:6 (Stephen's Speech)

\begin{tabular}{|c|c|c|}
\hline Gen 15:13 & Philo, Her. 266-7 & Acts 7:6 \\
\hline 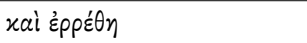 & 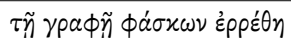 & 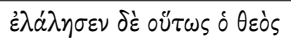 \\
\hline$\pi \rho$ s̀ $^{\prime} \mathrm{A} \beta \rho a ́ \mu$ & $\pi p o ̀ s ' A \beta p \alpha \alpha ́ \alpha$. & \\
\hline$\Gamma เ \nu \omega^{\prime} \sigma x \omega \nu \gamma \nu \omega^{\prime} \sigma n$ & 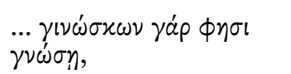 & \\
\hline 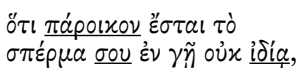 & 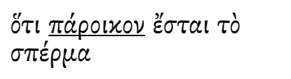 & 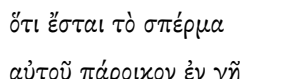 \\
\hline 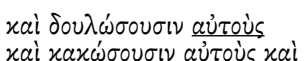 & 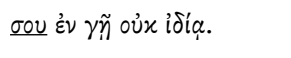 & ànotpía \\
\hline 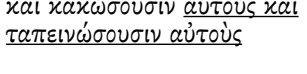 & & 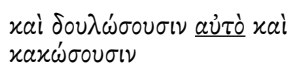 \\
\hline 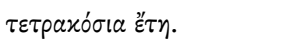 & & 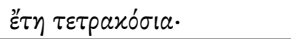 \\
\hline
\end{tabular}

Philo's quotation in Her. 266-7 is, apart from the parenthetic introductory formula $\gamma a ́ p ~ \phi \eta \sigma l$, in exact agreement with LXX Gen 15:13. Luke's quotation in Acts 7:6, however, creates the impression of a reference to the passage, i.e. a "retelling" in the form of an indirect quotation, rather than an explicit quotation. This becomes particularly clear in Luke's change of the second person singular pronoun бov to the third person singular pronoun a $\tau_{\tau} \tau \tilde{U}$ in Stephen's speech. Acts 7:6 presents some further differences when compared to the versions of LXX Gen 15:13 and Philo's Her. 266-7:

a) Transpositions: Пápoıxov is transposed after $\tau \dot{\partial} \sigma \pi \varepsilon ́ p \mu \alpha$ and before $\dot{\varepsilon} \nu \gamma \tilde{\eta}$;

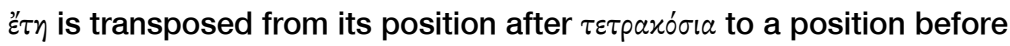

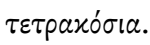

40 Barrett is of the opinion that v.25 is a conflation of Gen 12:3, 18:18, and 22:18 (2004:212).

41 For the relation between Gal 3:8 and Acts 3:25, cf. Steyn (1995:153), Koch (1986:222) and Jeremias (1969:88-94). 


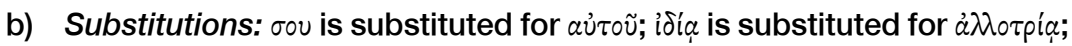

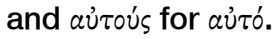

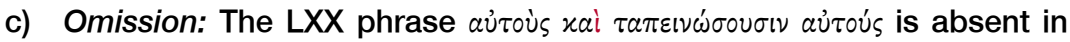
Acts 7:6 which makes the quotation (sic! reference) shorter than LXX Gen 15:13. Philo already ends his quotation with the words $\dot{\varepsilon} \nu \gamma \tilde{n}$ oủx ioi $\alpha$ so that it remains unknown whether his LXX version included or excluded this phrase.

None of the LXX or Philonic witnesses support any of these differences in Acts 7:6 - which largely confirm the differences in Acts to be due to Luke's interpretative hand and / or citation from memory. But the absence of the

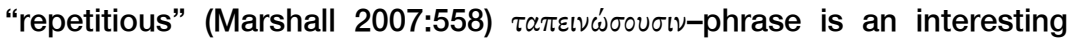
feature in the light of the MT. ${ }^{42}$ The Hebrew also lacks one of the elements listed, although not the same one:

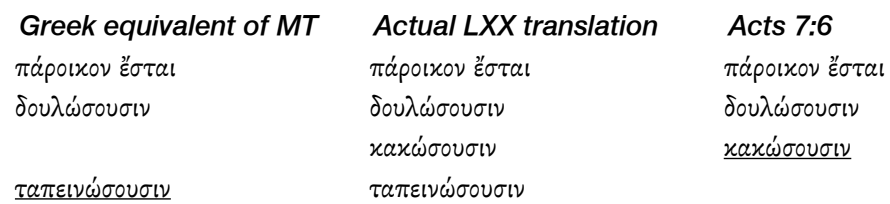

This points to closer alignment of Acts 7:6 with the LXX tradition than with the MT tradition.

42 "und sie werden sie erniedrigen: Die LXX hat drei gegenüber nur zwei Verben im MT, möglicherweise aufgrund von Doppelübersetzung der zweiten Verbform" (Karrer \& Kraus 2011:185). 
Case 5: The quotation from Gen 15:14 / Exod 3:12 in Acts 7:7 (Stephen's Speech)

\begin{tabular}{|c|c|c|c|c|}
\hline Gen 15:14 & Exod 3:12 & Philo, Her. 272 & $\begin{array}{c}\text { Philo, Fug. } \\
140\end{array}$ & Acts 7:7 \\
\hline 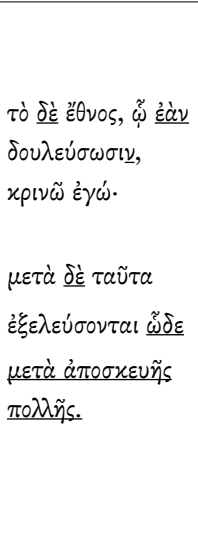 & 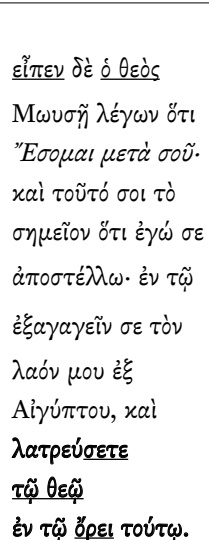 & 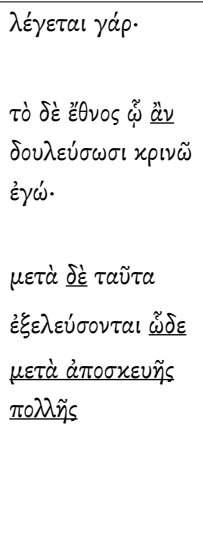 & $\begin{array}{l}\delta 1 \delta a ́ \sigma x \varepsilon \tau \alpha l \\
\chi p \eta \sigma \mu \tilde{\omega}, \\
o^{\prime} \tau l \\
\dot{\varepsilon}^{\prime} \sigma o \mu \alpha l \mu \varepsilon \tau \dot{\alpha} \sigma \sigma \tilde{v}\end{array}$ & 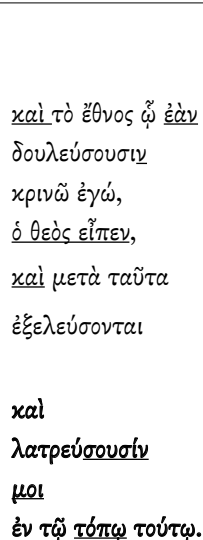 \\
\hline
\end{tabular}

Philo's quotation of LXX Gen 15:14 in Her. 272 is virtually identical, except for his use of $\alpha \ddot{\nu}$ in the place of $\varepsilon^{\alpha} \alpha$. The same applies to his brief quotation (reference?) of LXX Exod 3:12 in Fug. 140. Turning to Luke's quotation in Acts 7:7, there is little doubt that he presents a conflated quotation by using LXX Gen 15:14 for the first part of his quotation and Exod 3:12 for the second part. ${ }^{43}$ Apart from the parenthetic introductory formula

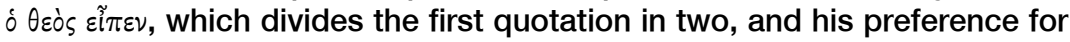
xai instead of $\delta \varepsilon$, is the rest of this first part of Luke's quotation identical to that LXX Gen 15:14. Luke then adds for the last part of his quotation a

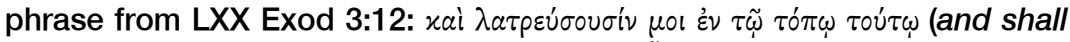
worship me in this place) - which replaces $\tilde{\omega} \delta \varepsilon \mu \varepsilon \tau \dot{\alpha} \dot{\alpha} \pi \circ \sigma x \varepsilon v \tilde{\eta} \varsigma \pi \circ \lambda \tilde{\eta}_{S}$ (with great possessions) of Gen 15:14. The quoted phrase from Exod 3:12 is, however, not identical to the LXX text. It is contextually and theologically reinterpreted by Luke in the mouth of Stephen when the second person plural $\lambda \alpha \tau \rho \varepsilon \dot{\sigma} \sigma \varepsilon \varepsilon$ becomes third person plural $\lambda \alpha \tau \rho \varepsilon \dot{\sigma} \sigma 0 u \sigma i v$; the reference to $\tau \tilde{\omega} \theta \varepsilon \tilde{\omega}$ is replaced with the first person $\mu$ ol (cf. $\delta \theta \varepsilon \dot{s} \varsigma \varepsilon i \tilde{\pi} \varepsilon v$ in the Gen 15:14

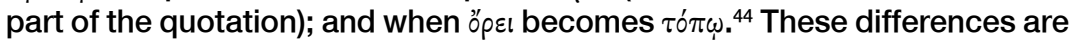

43 So similarly Conzelmann (1987:52): "There are clear echoes of Gen 15:13-14, with a touch from Exod 2:22, and an expansion from Exod 3:12". G. Schneider (1980:455) confirms: "Der Schluß von V 7 lehnt sich an Ex 3,12 an".

44 "...thus Sinai is replaced by Jerusalem or the Temple" (Conzelmann 1987:52). Also Barrett (2004:345). Pervo (2009:181) states, in turn: "By changing 
not supported by LXX or Philonic witnesses, which confirms that they are rather to be taken as interpretative alterations by Luke's hand than to an alternative Vorlage of the quotation(s).

Case 6: The quotation from Exod 1:8 in Acts 7:18 (Stephen's Speech)

\begin{tabular}{|c|c|c|}
\hline Exod 1:8 & Philo, Conf. 72 & Acts $7: 18$ \\
\hline 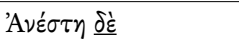 & 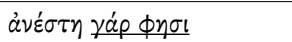 & 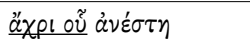 \\
\hline 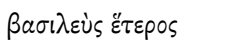 & 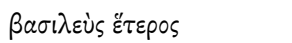 & $\beta a \sigma ı \lambda \varepsilon \dot{\varsigma} \varsigma$ हैं $\varepsilon \rho \circ \varsigma$ \\
\hline દ̇ $\pi^{\prime} \mathrm{A}^{\prime \prime} \gamma \cup \pi \tau \circ \nu$, ös oủx & 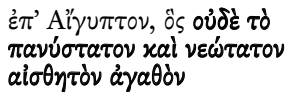 & ['̇ $\left.\pi^{\prime} \mathrm{A}^{\prime \prime} \gamma \cup \pi \tau \circ \nu\right]$ òs oủx \\
\hline 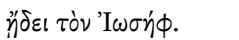 & 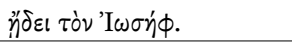 & 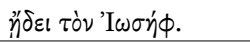 \\
\hline
\end{tabular}

Philo's quotation from Exod 1:8 in Config. 72 is longer and contains the

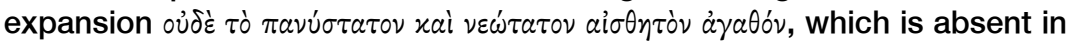
both the LXX and in Acts 7:18. Luke's version is thus closer to the LXX ${ }^{45}$ than to that of Philo. Acts 7:18 is connected with 7:17 by means of the áxpl

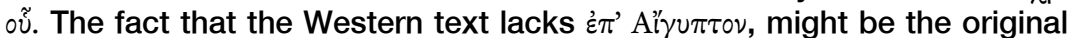
here as "there would be a tendency to assimilate to the LXX" (Barrett 2004:352; cf. Schneider 1980:458).

\section{SUMMARY AND CONCLUSION}

The explicit quotations from the Torah that overlap between Philo of Alexandria and the Acts of the Apostles are to be found in speeches of Peter and Stephen. Scripture, in this case the Torah, is thus quoted and interpreted by these authoritative figures in the Lukan writings. Differences between Luke's version and that of the LXX and Philo are minute and few in number. However, the following were observed:

- Case 1: Whereas the Markan trajectory, followed by Matthew, is closer to LXX Exod 3:6, all three of Luke's occurrences (Luke 20:37; Acts 3:13; 7:32) seem to be closer aligned to the textual tradition of LXX Exod 3:15. Firstly in the case of Luke $20: 37$ by using xúplos. Luke probably adjusted his quotation - originally taken from the Markan material used in Luke 20:37 - which aligns it closer to the same trajectory as that used by Philo. Luke's use of the accusative case is probably intended to present this as a reference rather than as an explicit quotation.

'mountain' to 'place', the 'Scripture' creates a link to v.33 and to the citation in v.49".

45 "Abgesehen von dem einleitenden äxpl oũ ist V 18 Zitat von Ex 1,8 LXX" (G. Schneider 1980:458). 
Secondly in the cases of Acts 3:13 and 7:32 due to their inclusion of the

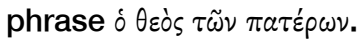

- Case 2: Luke presents an abbreviated version in Acts 7:3 of LXX Gen

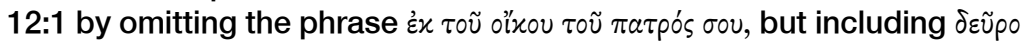
and hence emphasizing the aspects of movement and obedience. This might be due to his application of this passage in a new context, but it does not exclude the possibility of his Vorlage already lacking it (cf. the evidence of Targum Jonathan and several LXX witnesses). Luke is only closer to LXX Gen 12:1 with its inclusion of $\alpha 2 v$ before $\sigma 01 \delta \varepsilon i \xi \omega$ which lacks in Philo, but Philo's versions contain much longer sections from the LXX source text and are, apart from the absence of $\alpha \nu$, identical to the text form of LXX Gen 12:1-2.

- Case 3: Philo preserved both trajectories of the tradition, LXX Gen 12:3 as well as LXX Gen 22:18; 26:4-5. Paul, in turn, presents a conflated quotation by fusing together elements from the two versions. It is interesting to note that Luke clearly follows the second trajectory of the tradition - with two striking differences: the transposition of the phrase

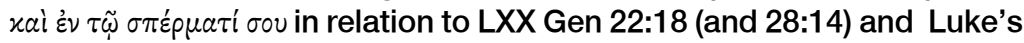

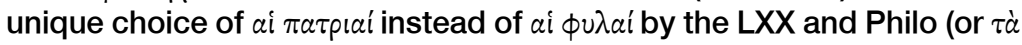
ह' $\theta \nu \eta$ by the LXX, Philo and Paul).

- Case 4: Although probably intended as a quotation, ${ }^{46}$ Acts 7:6 seems to be rather a paraphrase by Luke than evidence of another existing textual version of Gen 15:13. None of the LXX or Philonic witnesses support any of these differences in Acts 7:6 - which largely confirm the differences in Acts to be due to Luke's interpretative hand and / or citation from memory.

- Case 5: There is little doubt that Luke presents a conflated quotation in Acts 7:7 by using LXX Gen 15:14 for the first part of his quotation and Exod 3:12 for the second part. He has a clear theological reinterpretation in mind, influenced by LXX Exod 3:12, by including the

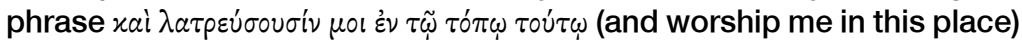
instead of the $\tilde{\omega} \delta \varepsilon \mu \varepsilon \tau \dot{\alpha} \alpha \dot{\alpha} \pi \circ \sigma x \varepsilon v \tilde{\eta} \varsigma \pi \circ \lambda \lambda \tilde{\eta} s$ (with great possessions) of LXX Gen 15:14 and Philo.

- Case 6: Luke's version in Acts 7:18 is closer to the LXX Exod 1:8 than

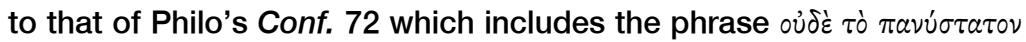

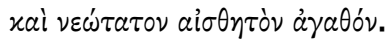

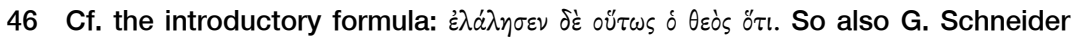
(1980:454). 
There were no clear traces found of another Textvorlage of the Torah that was used by Luke and/or Philo in the cases above. Luke's quotations in these instances resemble adaptations and interpretations already made in the Christian tradition by his time. A number of cases show evidence of conflations and paraphrases of the quoted passages. Noteworthy, however, is that Philo's text form and that of the reconstructed LXX text are very close in the cases investigated here. Where Philo notably differs from the reconstructed LXX text (cases 2 and 6 above), Luke tends to represent a text form that is in closer alignment to that of the LXX rather than that of Philo.

\section{BIBLIOGRAPHY}

Archer, G.L. \& Chirichigno, G. (EDS.)

1983. Old Testament Quotations in the New Testament. Chicago:Moody Press.

BARRETT, C.K.

2004. The Acts of the Apostles. Vol. 1. London:T\&T Clark, ICC.

Bietenhard, $\mathrm{H}$.

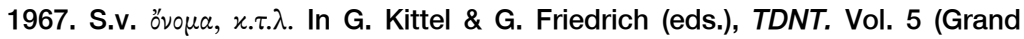
Rapids:Eerdmans), pp. 242-283.

Borgen, P., Fuglseth, K. \& Skarsten, R. (eds.)

2005. The Works of Philo: Greek Text With Morphology. Bellingham:Logos Bible Software.

Conzelmann, $\mathrm{H}$.

1987. Acts of the Apostles. Philadelphia:Fortress Press, Hermeneia.

Dell'Acqua, A.P. 2003. Upon Philo's Biblical Text and the Septuagint. In F. Calabi (ed.), Italian Studies on Philo of Alexandria (Leiden:Brill), pp. 25-52.

ELLIS, E.E. 1957. Paul's Use of the Old Testament. Grand Rapids:Baker Book House.

EMERTON, J.A.

1968. Review of M. Wilcox: "The Semitisms of Acts". JSS 13:282-297.

GASTON, L.

1987. Paul and the Torah. Vancouver:University of British Columbia Press.

JeremiAs, J.

1969. Paulus als Hillelit. In E.E. Ellis \& M. Wilcox (eds.), Neotestamentica et Semitica. Studies in Honour of Matthew Black (Edinburgh:T\&T Clark), pp. 88-94. 
Steyn Torah quotations common to Philo of Alexandria and the Acts

KarRer, M. \& Kraus, W. (eds.)

2011. Septuaginta Deutsch. Erläuterungen und Kommentare zum griechischen Alten Testament. Band 1: Genesis bis Makkabäer. Stuttgart:Deutsche Bibelgesellschaft.

Kraft, R.A.

2005. Philo's Bible Revisited. The 'aberrant texts' and their quotations of Moses. In F. García Martínez \& M. Vervenne (eds.), Interpreting translation: Studies on the LXX and Ezekiel in honour of Johan Lust (Leuven:Peeters Press), pp. 237-54.

Kilgallen, J.J.

1986. The Sadducees and Resurrection from the Dead: Luke 20:27-40. Bib 67:478-95.

$\mathrm{KoCH}$, D.-A.

1986. Die Schrift als Zeuge des Evangeliums. Untersuchungen zur Verwendung und zum Verständnis der Schrift bei Paulus. Göttingen:Vandenhoeck \& Ruprecht.

Marshall, I.H.

2007. Acts. In G.K. Beale \& D.A. Carson (eds.), Commentary on the New Testament Use of the Old Testament (Grand Rapids:Baker Academic), pp. 513-606.

McLean, B.H.

1992. Citations and Allusions to Jewish Scripture in Early Christian and Jewish Writings Through 180 C.E. Lewiston:Edwin Mellen Press.

Nolland, J.

1993. Luke: Vol. 3. Dallas:Word. WBC 35C.

Pervo, R.I.

2009. Acts. Minneapolis:Fortress Press. Hermeneia.

Pesch, R.

1986. Die Apostelgeschichte (Apg 1-12). Zürich:Benzinger Verlag. EKK V/1.

PorTer, S.E.

1999. Idioms of the Greek New Testament. Sheffield:JSOT.

Rese, M.

1979. Die Funktion alttestamentlichen Zitate und Anspielungen in den Reden der Apostelgeschichte. In J. Kremer (ed.), Les Actes des Apôtres - Traditions, redaction, théologie (Leuven:University Press, EThL 68), pp. 61-79.

RuNIA, D.T.

1993. Philo in Early Christian Literature. A Survey. Minneapolis:Fortress Press.

SCHNEIDER, G.

1980. Die Apostelgeschichte. 1. Teil. Freiburg:Herder. HThKNT V/1. 
SOISALON-SOININEN, I.

1987. Studien zur Septuaginta-Syntax. Helsinki:Academie Scientiarum Fennica. AASF 237.

STEYN, G.J.

1995. Septuagint Quotations in the Context of the Petrine and Pauline Speeches of the Acta Apostolorum. Kampen:Kok Pharos.

2006. Torah Quotations common to Philo, Hebrews, Clemens Romanus and Justin Martyr: What is the common denominator? In: C. Breytenbach, J.C. Thom \& J. Punt (eds.), The New Testament Interpreted: Essays in Honour of Bernard C. Lategan (Leiden:Brill, NT.S 124), pp. 135-51.

2012. Can we reconstruct an early text form of the LXX from the quotations of Philo of Alexandria and the New Testament? Torah Quotations overlapping between Philo and Galatians as a Test Case. In S. Kreuzer, M. Meiser \& M. Sigismund (eds.), Die Septuaginta III. Entstehung, Sprache, Geschichte (LXXconference Wuppertal 2010) (Tübingen:Mohr Siebeck, WUNT 286), pp. 444-64.

2013a. The Text Form of the Torah Quotations Common to the Corpus Philonicum and Paul's Corinthian Correspondence. In B. Koet, S. Moyise \& J. Verheyden (eds.), The Scriptures of Israel in Jewish and Christian Tradition: Essays in Honour of Maarten J. J. Menken (Leiden:Brill), pp. 193-210.

2013b. The text form of the Genesis quotations common to the Corpus Philonicum and Paul's Letter to the Romans. In G.J. Steyn (ed.), Reflecting on Romans. Essays in Honour of Andrie du Toit on the Occasion of his $80^{\text {th }}$ Birthday (Leuven:Peeters Press, Biblical Tools and Studies).

2013c. A Comparison of the Septuagint Textual Form in the Torah Quotations Common to Philo of Alexandria and the Gospels of Mark and Matthew. Journal of Septuagint and Cognate Studies 45:1-20.

SWETE, H.B.

1900. An Introduction to the Old Testament in Greek. Cambridge:University Press.

WeVERS, J.W.

1974. Genesis. Vol. 1. Göttingen:Vandenhoeck \& Ruprecht.

1991. Exodus. Vol. II,1. Göttingen:Vandenhoeck \& Ruprecht.

1993. Notes on the Greek Text of Genesis. Atlanta:Scholars Press. SCS/SBL 35.

WILCOX, M.

1965. The Semitisms of Acts. Oxford:University Press.

Keywords

LXX Quotations

Philo of Alexandria

Acts of the Apostles
Trefwoorde

LXX Aanhalings

Filo van Aleksandrië

Handelinge van die Apostels 